\title{
Increase of the functional parameters of the gear pump of agricultural machinery by increasing its specific working volume
}

Chernovol M. ${ }^{1}$, Kuleshkov Yu. ${ }^{2}$

Central Ukrainian National Technical University, Prospekt Universytetskyi, 8, Kropyvnytskyi, 25006, Ukraine; e-

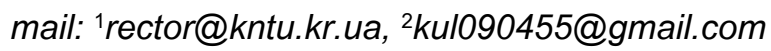

The purpose. To detect effect which originates during optimization of parameters of toothing of gear pump (GP). Methods. Theoretical-experimental methods of probe. On the basis of the developed mathematical model of process of feed of GP the design procedure is offered of optimum parameters of toothing, where parameter of optimization is the coefficient of use of volume of wreaths of sprockets. Results. During adaptation (to production conditions) of the construction of experimental pump with the augmented specific working volume they determined an opportunity of decreasing width of a cone at saving working volume of pump matching standard norms. It made it possible to reduce load on bearings of pump which primarily were responsible for reliability of the pump. New dependence is offered for account of load on bearings of pump, which in many aspects is determined by coefficient of overlapping of toothing. During designing the gear pump with optimum parameters and adaptation its operation parameters to standard norms they found synergetic effect, namely: decrease of overall dimensions and mass of the designed pump. Conclusions. The developed design procedure of parameters of toothing of rocking node of gear pump made it possible to design construction of GP with augmented specific working volume and feed. Thus coefficient of use of volume of wreaths of sprockets of the experimental pump grew up to 0,3323 , that on $11 \%$ was more than at serial pump, and working volume of pump reached $36,33 \mathrm{~cm} 3$, that on $14,6 \%$ was more than at serial pump. It stipulated synergetic effect which was implemented in lowering overall dimensions and mass of the designed pump.

Key words: gear pump, hydraulic fluid, toothing, working volume of pump, specific working volume of pump, synergetic effect.

https://doi.org/10.31073/agrovisnyk201901-08

On the basis of the developed mathematical model of the feeding process of a gear pump, the method for calculating toothing parameters with optimal parameters was suggested. As an optimization parameter, it was proposed to use the operation coefficient of the volume of gear rims.

The objective of the study was to identify the effect that takes place in the process of optimizing toothing parameters of the gear pump.

In the process of adapting the design of the experimental pump with increased specific working volume to the production conditions, it was possible to reduce the width of the gear having the same working volume of the pump. This working volume corresponds to the standard values. This allowed reducing the load on the pump bearings, which are mainly responsible for the reliability of the pump.

At the same time, a new correspondence was suggested for the calculation of the load on the bearings of the pump, which in many ways, as it turned out, is determined by the coefficient of overlapping of the toothing.

In the process of designing a gear pump with optimal parameters and adapting its operational parameters to the standard values, a synergistic effect was found which was expressed in reducing the overall dimensions and the weight of the designed pump by an amount significantly more significant than expected.

The method of calculating toothing parameters of the pumping unit has been developed, which allowed designing the gear pump with the increased specific working volume and feed. At the same time, the operation coefficient of the gear rims of the experimental pump increased to the value of 0.3323 , which is $11 \%$ more than that of a production pump. The working volume of the pump reached $36.33 \mathrm{~cm}^{3}$, which is $14.6 \%$ more than in the production pump This allowed appearing a synergistic effect, which is realized in reducing the overall dimensions and the weight of the designed pump at the value significantly more significant than expected.

gear pump, hydraulic oil, toothing, pump working volume, specific working volume of a pump, synergistic effect

Problem statement. 
В багатьох роботах попередніх дослідників моделювались робочі процеси подачі шестеренного насоса [1 - 13]. В окремих працях дослідження були спрямовані на підвищення робочого об'єму шестеренного насоса $[2,3,4,9,10,13]$. Але акцентована увага дослідженням спрямованим на підвищення саме питомого робочого об'єму шестеренного насоса (НШ) вченими не приділялась.

In our previous publications, it was found that a promising direction for raising the technical level of a gear pump is to increase the specific working volume of the pump (SWVP) [14-22].

On the basis of a more detailed study of the working flow of the hydraulic oil into the pump, we have developed a mathematical model that describes these processes in more details. This allowed us to develop the method for calculating toothing of the pumping unit with optimal parameters.

Under the optimal parameters of the toothing of the pump we shall understand the kind of toothing which provides the maximum value of the pump working volume (PWV) for the given design conditions, in particular the dimensions of the pump.

At the same time, we use the coefficient of using the volume of the gear rims as the optimality parameter [14 - 18]. The mathematical model of the coefficient of using the volume of the gear rims is the ratio of the working volume of the pump to the volume occupied by the gear rims of the pump. That is

$$
K_{v}=\frac{V_{0}}{D_{e}\left(0,25 \pi D_{e}+A\right)},
$$

where $V_{0}$ is the working volume of the pump, $\mathrm{mm}^{3}$;

$D_{e}$ is the diameter of gear tooth points, $\mathrm{mm}$;

$A$ is the c-c distance, $\mathrm{mm}$.

The working volume of the pump can be identified according to the correspondence [23, 24],

$$
V_{0}=0,5 \pi\left(D e^{2}-A^{2}-\frac{t_{0}^{2}}{3}\right)
$$

where $t_{0}$ is a tooth pitch on the base circle, $\mathrm{mm}$.

From the above-mentioned, we see that the SWVP depends on the parameters of the gear toothing with the corresponding limiting conditions, determines the technical level of toothing of the pumping unit and can be a criterion for optimizing the toothing of the pump at feeding.

On the basis of the proposed methodology, an experimental pump with the increased SWVP was designed and manufactured using the results of theoretical and experimental studies [21, 22]. The toothing calculated according to the proposed method and the corresponding design of the gear pump with increased SWVP, allows significantly increase the working volume of the pump and the feeding without changing the overall dimensions and the weight of the pump. But what is the benefit of this for the manufacturer and consumers of gear pumps?

The objective of this article is to determine technical and economic effect in case of increasing SWVP. The answer to this question is quite trivial at first glance: the increase of specific indicators leads to a decrease in overall dimensions and weight characteristics of the technical system while maintaining or even increasing its operational parameters.

There are facts that confirm this information. The overall dimensions of the experimental gear pump 32-E, designed according to the suggested methodology with the increased specific working volume, remained practically unchanged. However, the operation coefficient of the volume of the gear rims of the experimental pump has increased to the value of 0.3323 , which is $11 \%$ more than in a production pump, and the pump working volume reached the value of $36.33 \mathrm{~cm}^{3}$, which is $14.6 \%$ more than in the production pump. The specific power, that is, the power per unit of the weight of the experimental gear pump $32-\mathrm{E}$ is by $17 \%$ higher compared to the production pump [16, 18].

Such a significant increase in the functional parameters of the experimental gear pump 32-E became possible due to the use of the proposed method for calculating the toothing with optimal parameters and the corresponding design of the pump.

The gear pump in its design and manufacturing process is an open technical system. In addition, according to the results of the studies described in [16, 18], it was established that the correspondence of the parameter under investigation and the operation coefficient of the volume of gear rims to the parameters of toothing is nonlinear. In the process of designing and manufacturing all the design parameters of the pump interact. These facts indicate that there are necessary conditions for the emergence of a synergistic effect. The identification of the latter is the task of this publication. 
Adaptation of the design of the experimental gear pump with the increased specific working volume to production conditions. In the world practice, in order to increase the efficiency of the organization of production, all pumps are divided into standard series. In Ukraine, the following standard series are used: 1, 2, $(2,5), 3,4$, and 5. Each standard series differs in its type of toothing. The most mass produced pumps of the 3rd standard series with the working pump volume $V_{0}=20 \ldots 50 \mathrm{~cm}^{3}$, and among them there is a pump $V_{0}=32$ with working pump volume $\mathrm{cm}^{3}$. The transition from one size to another within a standard size series is carried out by changing the width of the gear rim - $b$.

In the process of optimizing toothing the pumping device we got the gear pump with the working volume of $\mathrm{cm}^{3}$. To change the working volume of the experimental gear pump to the standard value $\mathrm{ofm}^{3}$ it is necessary to reduce the width of the gear. Reducing the width of the gears decreases the load on the bearings, which creates objective preconditions for reducing their length, and hence the height of the whole pump. That is, unanticipated reduction of dimensions and the weight of the gear pump.

It is known that bearings are the most important elements that are primarily responsible for the operation life of the gear pump. The load on bearings of a gear pump is determined under the simplified formula according to the following empirical correspondence $[10,11,23,24]$

$$
F=K p b D_{e}
$$

where $p$ is the pressure developed by the pump, $\mathrm{Pa}$;

$b$ is the width of the gear, $\mathrm{m}$;

$D_{e}$ is the outer diameter of the gears, m;

$K=0,75 \ldots 0,85$ is the coefficient of proportionality.

There are other estimates of the proportionality coefficient $K=0,65 \ldots 1,15$. However, the professional literature does not include information on the principles of choosing this coefficient, and such a large spread of values of the coefficient $\mathrm{K}$ is due to its experimental definition for various pump sizes. In this case, according to the formula (3), for all kinds of toothing, regardless of their parameters, one and the same estimate of the coefficient of proportionality is given $K=0,85[10,11,23,24]$.

To answer this, let us ask ourselves why the proportionality coefficient is not equal to one $K=1$ ? The answer is obvious: it is explained by the fact that part of the area of the gear, which is influenced by the hydraulic forces, is closed from their influence by the gear that comes into contact with it. In other words, the coefficient of proportionality in (3) is determined by the coefficient of overlapping of toothing in the gear pump.

We suggest the correspondence to determine the averaged load on thegear, which takes into account the effect on this load of the overlapping factor of toothing in the gear pump

$$
F=\frac{p \cdot b \cdot G}{2}=p \cdot b \cdot \frac{A+D_{e}}{2}
$$

where $A$ is the c-c distance, $\mathrm{m}$;

$G$ is the length of the bigger axle of the gear pump, $m$;

$D_{e}$ is the outer diameter of the gears, m;

$b$ is the width of the gears, $\mathrm{m}$.

In this case, the degree of the influence of the overlapping coefficient of toothing will be taken into account automatically for each kind of toothing under consideration. This can be understood from the following considerations. The overlapping coefficient of toothing can be determined according to the correspondence $[23,24]$

$$
\varepsilon=\frac{\sqrt{D_{e}^{2}-d_{0}^{2}}-A \sin \alpha}{t_{0}},
$$

where $D$ is the outer diameter of the gears of the pump, $\mathrm{mm}$;

$d_{0}$ is the diameter of the main circle, $\mathrm{mm}$;

$A$ is the c-c distance, $\mathrm{mm}$;

$\alpha$ is the angle of toothing, degrees; 
$t_{0}$ is the tooth pitch, $\mathrm{mm}$.

With the help of the correspondence (5) we can find out the c-c distance by the formula

$$
A=\frac{\sqrt{D_{e}^{2}-d_{0}^{2}}-\varepsilon \cdot t_{0}}{\sin \alpha},
$$

And if we take into account that the toothing pitch can be calculated as

$$
t_{0}=m \pi \cos \alpha_{0}
$$

then correspondence (6) will be the following

$$
A=\frac{\sqrt{D_{e}^{2}-d_{0}^{2}}-\varepsilon m \pi \cos \alpha_{0}}{\sin \alpha}
$$

Taking into consideration that $[23,24]$ :

$$
\begin{gathered}
D_{e}=\frac{d_{0}}{\cos \gamma_{e}} \\
d_{0}=m z \cos \alpha_{0}
\end{gathered}
$$

where $m$ is the construction unit of toothing, $\mathrm{mm}$;

$z$ is the number of teeth of the gears;

$\gamma_{e}$ is the angle of the involute profile of the tooth point, degrees;

$\alpha_{0}$ is the angle of the original profile, degrees,

we shall have

$$
A=m \cos \alpha_{0} \frac{z \operatorname{tg} \gamma_{e}-\varepsilon \pi}{\sin \alpha}
$$

The loading of the hydraulic forces that influence the pump gears can be determined according to the correspondence (4). Then substituting the corresponding expressions (11) and (13) in (12), we obtain a definite result

$$
\begin{aligned}
F & =0,5 p b\left(m \cos \alpha_{0} \frac{z \operatorname{tg} \gamma_{e}-\varepsilon \pi}{\sin \alpha}+D_{e}\right), \\
\text { or } \quad F & =0,5 p b m z \cos \alpha_{0}\left(\frac{\operatorname{tg} \gamma_{e}-\varepsilon \pi}{\sin \alpha}+\frac{1}{\cos \gamma_{e}}\right) .
\end{aligned}
$$

After calculating the load on the gear wheels of the pump 32UK according to the correspondence (3) with $K=0,85$ and in accordance with the obtained correspondence (12) or (13), respectively, we obtain:

$$
\begin{gathered}
F_{1}=0,85 \cdot 16 \cdot 22 \cdot 55=16456 \mathrm{H} ; \\
F_{2}=16 \cdot 22 \frac{45+55}{2}=17600 \mathrm{H} .
\end{gathered}
$$

As can be seen from the above calculations, the proposed correspondence (12) gives a somewhat high estimate of the load (by 6.5\%), which prevents underestimation of the load on gears.

From the foregoing, it follows from the assumption that, adjusting the working volume of the experimental gear pump from the calculated $V_{0}=36,33 \mathrm{~cm}^{3}$ to the standard $V_{0}=32,0 \mathrm{~cm}^{3}$ by reducing the width of the gear from $22 \mathrm{~mm}$ to $19 \mathrm{~mm}$, it is possible to expect a reduction in the load on the gear tongues, which will make it possible to reduce their length. The pressure on the tongues of the gears was proposed to be determined according to the correspondence:

$$
p_{u}=\frac{p b\left(A+D_{e}\right)}{4 d_{u} L_{u}}
$$

where $d_{u}$ is the diameter of the tongues, $\mathrm{mm}$;

$L_{u}$ is the length of one tongue, $\mathrm{mm}$.

The results of calculations of the pump parameters are presented in the Table. Analyzing the obtained data, 
we see that when the working volume of the experimental pump is adjusted to a serial level by reducing the width of the gear to $19 \mathrm{~mm}$, the load on the gears, and, accordingly, on the tongues of the gears is reduced by $13 \%$. This gives the possibility of a proportional reduction in the length of the gear tongues, and hence the height of the pump as a whole.

Table. The main technical characteristics of the adapted experimental gear pump 32 - E with the increased specific working volume compared to a serial pump

\begin{tabular}{|l|c|c|}
\hline \multirow{2}{*}{ Technical parameter } & \multicolumn{2}{|c|}{ Technical parameters } \\
\cline { 2 - 3 } & Production pump & Experimental pump \\
\hline 1. Pump model & HШ-32-3 УK & HШ-32-E YPOH \\
\hline 2. Gear diameter, $D e, \mathrm{~mm}$ & 55,0 & 56,0 \\
\hline 3. Diameter of tongues $d_{z}, \mathrm{~mm}$ & 25 & 25 \\
\hline 4. Length of the bigger axle $G=A+D_{e}, \mathrm{~mm}$ & 100 & 101 \\
\hline 5. Working volume of the pump $V_{0}, \mathrm{~cm}{ }^{3}$ & 31,7 & 31,7 \\
\hline 6. Working volume of the pump $b, \mathrm{~mm}$ & 22,0 & 19,0 \\
\hline 7. Nominal pressure, MPa & 16,0 & 16,0 \\
\hline 8. Total length of tongues $27 \times 2, \mathrm{~mm}$ & 54 & 54 \\
\hline 9. Load on gears, $\mathrm{H}$ & 17600 & 15352 \\
\hline 10. Pressure on gear tongues, MPa & 13,04 & 47 \\
\hline 11. Total length of tongues after adjustment, $\mathrm{mm}$ & 54 & 13,07 \\
\hline 12. Pressure on gear tongues after adjustment, MPa & 13,04 & \\
\hline
\end{tabular}

Reducing the total length of the tongues from $54 \mathrm{~mm}$ to $47 \mathrm{~mm}$ (see Table) allows distributing the load on the gear tongues to the level corresponding to the production pump. Thus, due to the optimized parameters of the proposed toothing, it was possible to reduce the height of the gears by $10 \mathrm{~mm}$, which means that the height of each bushing can also be reduced by $3.5 \mathrm{~mm}$, and the height of the housing by $10 \mathrm{~mm}$. Therefore toothing with the optimal parameters offered allows reducing material consumption, energy intensity and the cost of manufacturing gear pumps by reducing its overall dimensions and dimensions of its elements by at least $10 \%$.

Thus, in the process of adaptation of the design of the experimental gear pump sufficient conditions were created to obtain synergistic effect: due to the increase of the specific working volume of the pump it became possible to reduce the width of the gears, which enabled reducing the load on the gear tongues and, accordingly, it was possible to reduce their length. Reducing the length of the tongues allowed reducing both the overall dimensions and the weight of the pump as a whole by the value significantly higher than expected.

The estimated annual economic effect from the introduction of the proposed changes in the design of the gear pump is $25 \ldots 40 \mathrm{UAH}$. per a pump. The economic effect is achieved by reducing the cost of materials and the manufacture of parts with reduced sizes: the width of the gear rims and gear tongues, which reduces the height of the bushings and the housing of the pump in general.

\section{Conclusions:}

1. The developed methodology for calculating the parameters of toothing of the pumping unit made it possible to design a gear pump with the increased specific working volume and feeding. At the same time, the operation coefficient of the volume of the gear rims of the experimental pump increased to the value of 0,3323 which is $11 \%$ higher than in a production pump, and the working volume of the pump reached the value of 36,33 $\mathrm{cm}^{3}$, which is $14,6 \%$ higher than in a production pump. The specific power is $17 \%$ higher compared to a production pump.

2. A synergistic effect was found out in the process of designing a gear pump with optimal parameters and adapting its operating parameters to the standard values. The effect was realized in reducing the overall dimensions and the weight of the designed pump on the value significantly higher than expected.

3. The estimated annual economic effect from the introduction of the proposed changes in the design of the 
gear pump is $25 \ldots 40 \mathrm{UAH}$. per a pump. The economic effect is achieved by reducing the cost of materials and manufacturing of the parts with reduced sizes.

\section{Literature}

1. Prokofev V.N. (1948). Kolovratnyie rotornyie nasosyi: [Entsiklopedicheskiy spravochnik mashinostroitelya] Mashgiz, t. 12. P. 398 - 401. [in Russian].

2. Ryibkin E.A., Usov A.A. (1960). Shesterennyie nasosyi dlya metallorezhuschih stankov. G.: Mashgiz. 189 p. [in Russian].

3. Leonov A.E. (1960). Nasosyi gidravlicheskih sistem i mashin . Leonov A.E. M.-K.: Mashgiz,- 226 p. [in Russian].

4. Kudryavtsev P.R. (1963). Povyishenie tochnosti opredeleniya teoreticheskoy proizvoditelnosti shesterennyih nasosov . Kudryavtsev P.R. .. Trudyi GOSNITI. t.2. -S. 51 - 68. [in Russian].

5. Kulagin L.V., Demidov Yu.S., Prokofev V.N., Kondakov A.A. (Prokofev V.N. Ed.). (1968). Osnovyi teorii i konstruirovaniya ob'emnyih gidroperedach. M.: Vyisshaya shkola. $399 \mathrm{~s}$. [in Russian].

6. Kudryavtsev P.R. (1970). Povyishenie resursa shesterennyih nasosov. Tehnika v selskom hozyaystve. 3 S. 67-72. [in Russian].

7. Osipov A.F. (1971). Ob'emnyie gidravlicheskie mashinyi kolovratnogo tipa. Teoriya, konstruktsiya, proektirovanie. M.: Mashinostroenie,. 207 s. [in Russian].

8. Bashta T.M. , Rudnev S.S., Nekrasov B.B et al. (1982). Gidravlika, gidravlicheskie mashinyi i gidravlicheskie privodyi. M.: Mashinostroenie. 593 s. [in Russian].

9. Bashta T.M. (1967). Gidravlicheskie privodyi letatelnyih apparatov. 4-e izd. M.: Mashinostroenie, $495 \mathrm{~s}$. [in Russian].

10. Bashta T.M. (1974). Ob'emnyie nasosyi i gidravlicheskie dvigateli gidrosistem: [uchebnik dlya vuzov]. M.:Mashinostroenie, $606 \mathrm{~s}$. [in Russian].

11. Bashta T.M. (1977). Mashinostroitelnaya gidravlika: [spravochnoe posobie]. M.: Mashinostroenie. 672 s. [in Russian].

12. Bashta T.M. (1969). Ob'emnyie gidravlicheskie privodyi. M.: Mashinostroenie. $628 \mathrm{~s}$. [in Russian].

13. Lure Z.Ya., Kovalenko I.V. (2003). Matematicheskaya model kachayuschego uzla shesterennogo nasosa, kak ob'ekta mnogokriterialnoy optimizatsii. Vibratsii v tehnike i tehnologiyah. 3 (29). S.9-13. [in Russian].

14. Chernovol M.I., KulEshkov Yu.V. (2008). Osnovni napryami vdoskonalennya shesterennih nasosiv silskogospodarskoyi tehniki. VIsnik agrarnoyi nauki, 8. s. 52 - 54. [in Ukrainian].

15. Kuleshkov Yu.V., Osin R.A., Rudenko T.V., Matvienko A.A. (2008). Usovershenstvovanie matematicheskoy modeli mgnovennoy podachi shesterennogo nasosa. Zblrnik naukovih prats Klrovogradskogo natslonalnogo tehnlchnogo unlversitetu «Tehnlka $v$ sllskogospodarskomu virobnitstvl, galuzeve mashinobuduvannya, avtomatizatslya». KIrovograd, KNTU. 20. S. 253-262. [in Russian].

16. Kuleshkov Yu.V., Chernovol M.I., Rudenko T.V. Gutsul V.I., OsIn R.A. (2010). Doslldzhennya povedlnki matematichnoYi modell pitomogo robochogo ob'Emu shesterennogo nasosa tipu NSh vld parametrlv zubchastogo zacheplennya. Zblrnik naukovih prats Klrovogradskogo natslonalnogo tehnlchnogo unlversitetu. Tehnlka $v$ sllskogospodarskomu virobnitstvl, galuzeve mashinobuduvannya, avtomatizatslya Vipusk 23 KIrovograd, s. 278 390. [in Ukrainian].

17. Kuleshkov Yu.V., Rudenko T.V. Osin R.A. (2009). Povyishenie udelnoy podachi shesterennogo nasosa. MOTROL Motorization and Power Industry in Agriculture. Volume 11A. Simferopol - Lublin S.193. 206.

18. Chernovol M.I., KulEshkov Yu.V. (2011). Optimlzatslya zubchastogo zacheplennya shesterennogo nasosa tipu NSh u napryami pidvischennya yogo pitomogo ob'Emu. Vlsnik agrarnoYi nauki, traven. 5. s. $42-45$. [in Ukrainian].

19. Shesterennyie nasosyi s asimmetrichnoy liniey zatsepleniya shesteren . [Kuleshkov Yu.A., Chernovol M.I., Bez O.V., Titov Yu.A.] ..Teoriya, konstruktsiya i raschet. Kirovograd: «KOD», 2009 - 243 s. [in Ukrainian].

20. Kuleshkov Yu.V. (2004). Otsenka metodov opredeleniya ob'emnoy podachi shesterennyih nasos NSh. Kuleshkov Yu.V. .. Zagalnoderzhavniy mlzhvldomchiy naukovo-tehnlchniy zblrnik «Konstruyuvannya, virobnitstvo ta ekspluatatslya sllskogospodarskih mashin». KIrovograd, KDTU. 34. S. 178-186. [in Russian].

21. KulEshkov Yu.V., Chernovol M.I., Magopets S.O., OsIn R.A., Rudenko T.V., Bevz O.V Sposlb pldvischennya pitomogo robochogo ob'Emu shesterennih gldromashin Patent na korisnu model (UkraYina). 29840 vld 25.01.2008 r. V23R [in Ukrainian]. 
22. KulEshkov Yu.V., Rudenko T.V., OsIn R.A., Kroplvna A. V., KulEshkova K.Yu. (2009). Sposib pidvischennya pitomogo robochogo ob'Emu shesterennih gldromashin. Patent na korisnu model (Ukrayina). 40093. 25.03.2009. Byul. 6 [in Ukrainian].

23. Yudin E.M. (1964). Shesterennyie nasosyi. Osnovnyie parametryi i ih raschet. Yudin E.M. [2-e izd. pererab. i dop.]. M.: Mashinostroenie, 236 s. [in Russian].

24. Chinyaev I.A. (1969). Rotornyie nasosyi: [spravochnoe posobie]. L.: Mashinostroenie. 216 p. [in Russian]. 